\title{
Novel histone deacetylase inhibitors in clinical trials as anti-cancer agents
}

\author{
Jiahuai Tan', Shundong Cang ${ }^{2}$, Yuehua Ma ${ }^{3}$, Richard L Petrillo', Delong Liü ${ }^{3 *}$
}

\begin{abstract}
Histone deacetylases (HDACs) can regulate expression of tumor suppressor genes and activities of transcriptional factors involved in both cancer initiation and progression through alteration of either DNA or the structural components of chromatin. Recently, the role of gene repression through modulation such as acetylation in cancer patients has been clinically validated with several inhibitors of HDACs. One of the HDAC inhibitors, vorinostat, has been approved by FDA for treating cutaneous T-cell lymphoma (CTCL) for patients with progressive, persistent, or recurrent disease on or following two systemic therapies. Other inhibitors, for example, FK228, PXD101, PCI-24781, ITF2357, MGCD0103, MS-275, valproic acid and LBH589 have also demonstrated therapeutic potential as monotherapy or combination with other anti-tumor drugs in CTCL and other malignancies. At least 80 clinical trials are underway, testing more than eleven different HDAC inhibitory agents including both hematological and solid malignancies. This review focuses on recent development in clinical trials testing HDAC inhibitors as anti-tumor agents.
\end{abstract}

\section{Background}

Histones are among the most evolutionarily conserved proteins and the most abundant proteins bound to DNA in eukaryotic cells [1]. There are a total of five classes of them $(\mathrm{H} 1, \mathrm{H} 2 \mathrm{~A}, \mathrm{H} 2 \mathrm{~B}, \mathrm{H} 3$, and $\mathrm{H} 4)$ organized into two groups: core histones (H2A, H2B, H3 and H4) and linker histone (H1). Two each of the core histones form nucleosome particle by wrapping 147 base pairs of DNA. Histone $\mathrm{H} 1$, as a linker, binds nucleosomes together and thus participates in a higher-order of histones as chromatin [2-4]. Chromatin undergoes modifications by changing its structure and chemical composition as cells differentiate, subsequently lead to diverse patterns of gene expression and differences in cellular function [5]. Such post-translational modifications are called epigenetic processes and are inheritable changes in gene expression without alteration of the nucleotide sequence [6]. These modifications in the chromatin including genomic DNA and histones or other chromatin-associated proteins comprise the addition of methyl, acetyl, and phosphoryl groups or even larger moieties such as binding of ubiquitin or small ubiquitin-like modifier $[7,8]$. Out of all the modifications

\footnotetext{
* Correspondence: delong_liu@nymc.edu

${ }^{3}$ Division of Oncology/Hematology, New York Medical College, Valhalla, NY 10595, USA
}

above, histone acetylation is the most widely studied and has been shown to have diverse roles in the regulation of the nucleosome. Lysine acetylation, for example, can lead to changes in chromatin structure and may decrease the histone-DNA interaction and promote accessibility of the DNA for transcription activation [9]. The abnormal activation and deactivation of transcription based on histone acetylation status may be associated with tumorigenesis [10]. Several lines of evidence indicated that HDACs are associated with a number of well-characterized cellular oncogenes and tumor suppressor genes leading to development of many specific forms of malignancy [11,12].

In the eukaryotic cells, 18 different HDACs are identified and they may reside either in the nucleus or in the cytoplasm [13,14]. According to phylogenetic analyses and sequence homologies with yeast proteins, HDACs can be divided into four classes. Class I family of HDACs consists of 1, 2, 3 and 8 proteins. They are similar to yeast HDACs and locate in the nucleus of the cells exclusively $[15,16]$. Class II family members include 4, 5, 6, 7, 9 and 10, which are related to Hos3 in yeast. They primarily localize in the cytoplasm, but can transfer to nucleus from cytoplasm $[17,18]$. Class I and II of HDACs are evolutionarily related and share a common enzymatic mechanism, the Zn-catalyzed hydrolysis of 
the acetyl-lysine amide bond [19]. HDAC11 is located in both cytoplasm and nucleus and belongs to class IV [20]. It has a conserved domain in the catalytic region and shares features with both class I and II. The class III of HDACs is the so-called Sirts, consisting of seven members. These proteins are similar to Sirts in yeast. They are different with previous groups and are $\mathrm{Zn}$ independent and dependent on NAD as a cofactor [21].

Inhibitors of HDACs were found to have anti-cancer function as a novel therapeutic class of drugs in many different cancers [22-26]. Based on their chemical structure, these inhibitors can be subdivided into four different classes, including hydroxamates, cyclic peptides, aliphatic acids and benzamides [27]. TSA, a compound of hydroxamates, is the first nature product that has been discovered to possess the HDAC inhibitor activity in1990. Its structural analog, suberoyl anilide hydroxamic acid (SAHA) was the first approved HDAC inhibitor for clinical treatment of $\mathrm{T}$ cell lymphoma. Other compounds, for example, CBHA [28,29] and LBH589 [30-32], have been used in pre- and clinical trials in this group. Another class of HDAC inhibitors is aliphatic acid, including Valproic acid (VPA) [33-35], phenylbutyrate [36]. The third group is benzamide consisted of MS-275 [25,37-41] and MGCD0103 [42-45]. The last group is cyclic peptide including FK-228 [46-50].

Although not fully understood, the clinical activity of these inhibitors is thought to be mediated in part by induction of histone acetylation, resulting in a permissive or more open chromatin configuration and potential reactivation of aberrantly suppressed genes resulting in growth arrest, cell differentiation, and apoptosis of tumor cells [51-55]. The patterns of alterations of gene expression are similar for different HDAC inhibitors, but show definite differences induced by different agents in various transformed cells [56-58]. Functionally, HDACs regulate gene expression by at least three mechanisms [59]. First of all, histone deacetylation increases the charge density on the $\mathrm{N}$-termini of the core histones, thereby strengthening histone tail-DNA interactions and blocking access of the transcriptional machinery to the DNA template. In addition, histone modifications are specifically recognized by chromatininteracting proteins [14]. A consequence of this alteration in nucleosome conformation is reduced accessibility of the transcriptional regulatory machinery to the DNA template, resulting in transcriptional repression [60-63]. A second mechanism by which HDACs regulate transcription is by catalyzing the deacetylation of sequencespecific DNA binding transcription factors. Acetylation and deacetylation of sequence-specific transcription factors can either increase or decrease their DNA binding activity, and subsequently may enhance or repress transcription [64-68]. Furthermore, a number of cytoplasmic proteins, including tubulin and HSP90, have now been shown to be acetylated by HDAC [69-73]

One of the HDAC inhibitors, vorinostat, has been approved by FDA for treating cutaneous T-cell lymphoma (CTCL) for patients with progressive, persistent, or recurrent disease on or following two systemic therapies. Other inhibitors, for example, FK228, PXD101, PCI-24781, ITF2357, MGCD0103, MS-275, valproic acid and LBH589 have also demonstrated therapeutic potential as monotherapy or combination with other antitumor drugs in CTCL and other malignancies. At least 80 clinical trials are underway, testing more than eleven different HDAC inhibitory agents including both hematological and solid malignancies. Vorinostat clinical trials have been updated lately [13,74]. This review focuses on recent development in clinical trials testing newer HDAC inhibitors as anti-tumor agents.

\section{PCl-24781}

PCI-24781 (formerly CRA-024781) is a broad-spectrum phenyl hydroxamic acid. It has been evaluated alone or with ionizing radiation and other DNA-damaging agents in pre-clinical studies [75]. Recent pre-clinical data have suggested that it may act, in part, by inhibiting DNA repair resulted in a synergistic effect on apoptosis when combined with other agents [76,77]. Phase I clinical trial in refractory advanced solid tumor patients showed that PCI-24781 was well tolerated following intravenous or oral administration. Adverse events included anemia, thrombocytopenia, diarrhea, nausea, fatigue, and vomiting. Only one patient in the final cohort had asymptomatic non-specific ST- T wave changes and had drug discontinued. These were not dose-related. Mean oral bioavailability was 0.28 (34\%) with no difference between solution and capsule. Tubulin and histone acetylation were documented in peripheral blood mononuclear cells (PBMCs). Acetylation levels increased at $1.5 \mathrm{~h}$ post dose and were sustained through $4 \mathrm{~h}$ in all patients. Stable disease up to 8 cycles was seen in 5 of 13 evaluable patients [78].

\section{ITF2357}

ITF2357 is a synthesized HDAC inhibitor containing a hydroxamic acid moiety linked to an aromatic ring. Many reports demonstrated that it has inhibitory activity in the production of pro-inflammatory cytokines, as well as cytotoxic activity both in vitro on several human tumor cell lines and in vivo in patients with hematologic malignancies [79-83]. A phase II open label non randomized study was done at the National Tumor Institute of Milan using the drug as third-line or higher treatment of heavily pretreated, relapsed or refractory, Hodgkin lymphoma (HL) patients. Toxicity included: grade 1 leukopenia in 30\%, grade 2 thrombocytopenia in 33\%, fatigue in $50 \%$, grade 1 diarrhea and/or abdominal pain in 40\%; prolongation of QTc interval prompting 
transient drug discontinuation in $20 \%$. Thirteen patients completed at least one cycle of therapy and were evaluated for response. Seven patients (54\%) had stable disease by CT scan that was associated with a significant reduction in FDG-PET uptake in 6 patients (46\%) lasting a median of 3 months. Six patients had progression of disease (POD). Preliminary results in this series of very heavily pretreated HL patients showed that oral ITF 2357 has anti-tumor activity and a good safety profile. The drug warrants additional studies, alone and in combination, as salvage treatment for HL even with less advanced disease [84].

\section{MS-275 (SNDX-275)}

MS-275 is a synthetic benzamide derivative that has been shown to inhibit HDACs, and has anti-tumor activity in many preclinical models [25,85-88]. Clinical trial with this agent was first done in the patients with advanced solid tumors or lymphoma in 2005 (Table 1). They were treated with MS-275 orally initially on a once daily $\times 28$ every 6 weeks schedule. The starting dose was $2 \mathrm{mg} / \mathrm{m}^{2}$ and the dose was escalated in threeto six-patient cohorts based on toxicity assessments. With the daily schedule, the maximum tolerated dose (MTD) was exceeded at the first dose level. Therefore, once every 14 days schedule was implemented and found reasonably well tolerated. The MTD was $10 \mathrm{mg} /$ $\mathrm{m}^{2}$ and dose-limiting toxicities (DLTs) were nausea, vomiting, anorexia, and fatigue. HDAC inhibition was observed in PBMCs. Preliminary pharmacokinetics (PK) analysis suggested the half-life of MS-275 in humans was 39 to 80 hours, substantially longer than predicted by preclinical studies. Based on PK data, a more frequent dosing schedule, weekly $\times 4$, repeated every 6 weeks is being evaluated [89]. A total of 22 patients were enrolled on this schedule, and 19 were considered evaluable for toxicity. The MTD was $6 \mathrm{mg} / \mathrm{m}^{2}$. No grade 4 toxicities were observed. DLTs were reversible and consisted of hypophosphatemia, hyponatremia, and hypoalbuminemia. MS-275 was found to be well tolerated at a dose of $6 \mathrm{mg} / \mathrm{m}^{2}$ administered weekly with food for 4 weeks cycled every 6 weeks [90].

Three additional dose schedules were also studied: once every other week, twice weekly for 3 weeks every
28 days, and once weekly for 3 weeks every 28 days. MS-275 was confirmed to be safe and well tolerated at doses up to $6 \mathrm{mg} / \mathrm{m}^{2}$ every other week or $4 \mathrm{mg} / \mathrm{m}^{2}$ weekly for 3 weeks followed by 1 week of rest. These two schedules resulted in biologically relevant plasma concentrations and anti-tumor activity. Levels of histone $\mathrm{H} 3$ and $\mathrm{H} 4$ acetylation in PBMCs increased. Two of 27 patients showed partial remissions (PR), including one patient with metastatic melanoma who had a PR and has remained on study for $>5$ years. Six patients showed prolonged disease stabilization (SD). Twice-weekly dosing was not tolerable due to asthenia, and further evaluation of this schedule was halted. The recommended dose for further disease-focused studies is $4 \mathrm{mg} / \mathrm{m}^{2}$ given weekly for 3 weeks every 28 days or 2 to $6 \mathrm{mg} / \mathrm{m}^{2}$ given once every other week [91].

Phase 1 study in advanced acute leukemias also demonstrated that MS-275 was safe and can be tolerated at doses up to $8 \mathrm{mg} / \mathrm{m}^{2}$ weekly for 4 weeks every 6 weeks. The patients were treated with MS-275 initially once weekly $\times 2$, repeated every 4 weeks from 4 to 8 $\mathrm{mg} / \mathrm{m}^{2}$, and after 13 patients were treated, once weekly $\times 4$, repeated every 6 weeks from 8 to $10 \mathrm{mg} / \mathrm{m}^{2}$. DLTs included infections and neurologic toxicity manifesting as unsteady gait and somnolence. Other frequent nonDLTs were fatigue, anorexia, nausea, vomiting, hypoalbuminemia, and hypocalcaemia. Histone $\mathrm{H} 3 / \mathrm{H} 4$ acetylation, p21 expression, and caspase- 3 activation can be induced by MS-275 in bone marrow mononuclear cells. Even though MS-275 effectively inhibits HDAC in vivo in patients with advanced myeloid leukemias, responses by classical criteria were not seen [92].

Pre-clinical studies suggested that combining inhibitors of DNA methyltransferase (DNMT), 5-azacitidine (AZA), with inhibitors of HDAC, SNDX-275, synergistically induced re-expression of epigenetically-silenced tumor suppressor genes and had anti-tumor effect. Clinical study revealed it safe and well tolerated in 10 patients with advanced non small cell lung carcinoma (NSCLC). AZA was given subcutaneously on days 1-6 and 8-10 with SNDX-275 (MS-275) at a fixed dose of 7 $\mathrm{mg} /$ day on days 3 and 10 of a 28 day cycle. No DLT was seen in the $30 \mathrm{mg} / \mathrm{m}^{2}$ dose cohort. At $40 \mathrm{mg} / \mathrm{m}^{2}$,

Table 1 Clinical studies of MS-275 (SNDX-275)

\begin{tabular}{|c|c|c|c|c|c|}
\hline Phase & $\begin{array}{l}\text { Other } \\
\text { agent }\end{array}$ & Disease (pt. No.) & Schedule & $\begin{array}{l}\text { Recommended } \\
\text { dose }\end{array}$ & Reference \\
\hline । & & Relapsed or refractory AML (39). & Once weekly for 4 weeks of a 6 week cycle & $8 \mathrm{mg} / \mathrm{m}^{2}$ & [92] \\
\hline I & & $\begin{array}{l}\text { Refractory solid tumors and } \\
\text { lymphoid(22) }\end{array}$ & Once weekly for 4 weeks of a 6 week cycle & $6 \mathrm{mg} / \mathrm{m}^{2}$ & [90] \\
\hline । & & $\begin{array}{l}\text { Refractory solid tumors and } \\
\text { lymphoid(27) }\end{array}$ & $\begin{array}{l}\text { Once weekly for } 3 \text { weeks of a } 4 \text { week cycle or once } \\
\text { every other week. }\end{array}$ & $4 \mathrm{mg} / \mathrm{m}^{2}$ & [91] \\
\hline । & & $\begin{array}{l}\text { Refractory solid tumors and } \\
\text { lymphoid }\end{array}$ & Once every 2 week of 6 week cycle. & $10 \mathrm{mg} / \mathrm{m}^{2}$ & [89] \\
\hline
\end{tabular}


one subject was replaced due to rapidly progressive disease during week 1 . One subject experienced a hematologic DLT (grade 3 neutropenia and thrombocytopenia). No long term adverse outcomes from the DLT were seen. Common low grade toxicities included injection site reactions, nausea/vomiting, constipation, fatigue, and cytopenias. A major and durable PR has been observed in one patient, which is ongoing at $>8$ months. Two patients had stable diseases through $\geq 2$ cycles of therapy; the remaining patients had PODs. This clinical trial showed that AZA and SNDX-275 combination may have clinical activity in advanced NSCLC patients after failing at least one previous chemotherapy regimen [93]. Depsipeptide (romidepsin, FK228, FR901228)

Depsipeptide (FR901228) is a bicyclic peptide isolated from Chromobacterium Violaceum and has demonstrated potent in vitro cytotoxic activity against human tumor cell lines and in vivo efficacy against human tumor xenografts. Sander et al first studied 37 patients with advanced or refractory neoplasm by utilizing depsipeptide by a 4-h intravenous infusion on days 1 and 5 of a 21-day cycle in 2002 (Table 2). DLT included grade- 3 fatigue (3 patients), grade- 3 nausea and vomiting ( 1 patient), grade- 4 thrombocytopenia ( 2 patients), and grade- 4 cardiac arrhythmia (1 patient, atrial fibrillation). Reversible ECG changes with ST/T wave flattening were regularly observed. There were no clinically significant changes in left ventricular ejection fraction. The recommended Phase II dose is $17.8 \mathrm{mg} / \mathrm{m}^{2}$ administered on day 1 and 5 of a 21-day cycle. One patient obtained a PR [94]. Other clinical study done in the similar population confirmed that depsipeptide can be safely administered when given as a 4-hour infusion and further clinical trials are warranted [95].
Patients with refractory renal cell cancer were enrolled on a multi-institutional, single-arm, phase II study. Patients received depsipeptide at $13 \mathrm{mg} / \mathrm{m} 2$ intravenously over 4 hours on days 1,8 , and 15 of a 28 -day cycle with disease reevaluation performed every 8 weeks. The most common serious toxicities were fatigue, nausea, vomiting, and anemia. Two patients developed a prolonged QT interval, one patient each developed grade 3 atrial fibrillation and tachycardia, and there was 1 sudden death. Two patients experienced an objective response for an overall response rate (ORR) of 7\% (95\% CI, 0.8\%-23\%). Depsipeptide at this dose and schedule was concluded to have insufficient activity for further investigation in this patient population [96].

Clinical trial in lung cancer exhibited minimal clinical efficacy. Nineteen patients with lung cancer refractory to standard therapy received 4-h depsipeptide infusions $\left(17.8 \mathrm{mg} / \mathrm{m}^{2}\right)$ on days 1 and 7 of a 21 -day cycle. Each full course of therapy consisted of two identical 21-day cycles. Nineteen patients were evaluated for toxicity assessment; 18 were evaluated for treatment response. Myelosuppression was dose limiting in one individual. No significant cardiac toxicities were observed. Maximum steady-state plasma depsipeptide concentrations ranged from 384 to $1114 \mathrm{ng} / \mathrm{mL}$. No objective responses were observed. Transient SD was noted in nine patients. It may warrant further evaluation of this HDAC inhibitor in combination with novel-targeted agents in lung cancer patients [97].

Chronic lymphocytic leukemia (CLL) and acute myeloid leukemia (AML) cells can be induced by depsipeptide into apoptosis in vitro. Clinical trial was done in ten patients with CLL and 10 patients with AML who were treated with $13 \mathrm{mg} / \mathrm{m}^{2}$ depsipeptide intravenously

Table 2 Clinical studies of romidepsin (depsipeptide)

\begin{tabular}{|c|c|c|c|c|c|}
\hline Phase & Other agent & Disease (pt. No.) & Schedule & $\begin{array}{l}\text { Recommended dose \& } \\
\text { response }\end{array}$ & Reference \\
\hline । & & $\begin{array}{l}\text { Advanced or refractory colorectal(11), renal (12) } \\
\text { and other neoplasms(14) }\end{array}$ & $\begin{array}{l}\text { Day } 1 \text { and } 5 \text { of a 21-day } \\
\text { cycle }\end{array}$ & $24.9 \mathrm{mg} / \mathrm{m}^{2}$ & [94] \\
\hline I & & Colorectal(8), breast(4), sarcoma(3) and other (15) & $\begin{array}{l}\text { Day } 1,8 \text {, and } 15 \text { of } 28- \\
\text { day cycle }\end{array}$ & $13.3 \mathrm{mg} / \mathrm{m}^{2}$ & [95] \\
\hline । & & CLL/AML(20) & $\begin{array}{l}\text { Day } 1,8 \text {, and } 15 \text { of } 28- \\
\text { day cycle }\end{array}$ & $13 \mathrm{mg} / \mathrm{m}^{2}$ & [98] \\
\hline । & Gemcitabine & Solid tumor(33) & $\begin{array}{l}\text { Days } 1,8 \text {, and } 15 \text { of a } \\
28 \text { day cycle }\end{array}$ & $12 \mathrm{mg} / \mathrm{m}^{2}$ & [101] \\
\hline । & & Solid tumors(26) & $\begin{array}{l}\text { Days } 1,3 \text {, and } 5 \text { of a } 28- \\
\text { day cycle }\end{array}$ & $9 \mathrm{mg} / \mathrm{m}^{2}$ & {$[100]$} \\
\hline$\|$ & & Renal cell carcinoma(42) & $\begin{array}{l}\text { days } 1,8 \text {, and } 15 \text { of a } \\
28 \text {-day cycle }\end{array}$ & $\begin{array}{l}13 \mathrm{mg} / \mathrm{m}^{2} \\
\text { OR } 7 \%\end{array}$ & [96] \\
\hline$|-| \mid$ & & MDS(3)/AML(9) & $\begin{array}{l}\text { Day } 1 \text { and } 5 \text { of a 21-day } \\
\text { cycle }\end{array}$ & $\begin{array}{l}18 \mathrm{mg} / \mathrm{m}^{2} \text { (CR .6\%, SD 46\%, POD } \\
30.7 \%, \mathrm{NA} 7.6 \%) .\end{array}$ & [99] \\
\hline$\|$ & & SCLC(3)/NSCLC(16) & $\begin{array}{l}\text { Day } 1 \text { and } 7 \text { of a } 21 \text { day } \\
\text { cycle }\end{array}$ & SD52\%, POD 48\%. & [97] \\
\hline
\end{tabular}


on days 1,8 , and 15 . Neither life-threatening toxicities nor cardiac toxicities were noted, although the majority of patients experienced progressive fatigue, nausea, and other constitutional symptoms that prevented repeated dosing. Depsipeptide effectively inhibits HDAC in vivo in patients with CLL and AML. Several patients had evidence of anti-tumor activity following treatment, but no PRs or complete responses (CRs) were noted. HDAC inhibition and histone acetylation increases of at least $100 \%$ were noted. Its use in the current schedule of administration is limited mainly by progressive constitutional symptoms [98]. Another study of depsipeptide was done in patients with myelodysplastic syndrome (MDS) or AML at a dose of $18 \mathrm{mg} / \mathrm{m} 2$ intravenously on days 1 and 5 every 3 weeks. Twelve patients (nine with AML, three with MDS) received one to five cycles of depsipeptide. The most common grade $3 / 4$ toxicities were febrile neutropenia/infection (five patients), neutropenia/thrombocytopenia (nine patients), nausea (nine patients), and asymptomatic hypophosphatemia (three patients). No clinically significant cardiac toxicity was observed. One of 11 assessed patients achieved CRs, six in SDs, and four in PODs. The results showed that depsipeptide therapy can be administered with acceptable short-term toxicity. Depsipeptide monotherapy however appears to have limited clinical activity in unselected AML/MDS patients [99].

Another phase I trial of depsipeptide was done following a new schedule. It was administered on days 1,3 and 5 to a group of twenty six patients with radioactive iodine (RAI)-refractory thyroid cancer. No grade 4 toxicities were observed. Eleven patients had SDs for a median of 28 weeks. Four patients have undergone follow up RAI scans; none had increased RAI uptake. The MTD was reached on this new schedule. This protocol is open exclusively for patients with RAI-refractory thyroid cancer [100].

The combination of depsipeptide and gemcitabine was evaluated in patients with advanced solid tumors. Depsipeptide was administered as a 4 hour infusion followed by gemcitabine over 30 minutes on days 1,8 , and 15 of a 28 day cycle. Thirty-three patients ( 9 pancreatic, 8 breast, 7 NSCLC, 3 ovarian, 6 other) have received 104+ cycles (median 2, range 1 - 8). Nonhematologic toxicities have been mild to moderate. These consisted primarily of nausea, vomiting, and fatigue. One patient with ovarian cancer experienced a minor response (29\%) and 12 patients experienced SDs after $\geq 4$ cycles. The phase II dose (depsipeptide $12 \mathrm{mg} / \mathrm{m}^{2}$ and gemcitabine $800 \mathrm{mg} / \mathrm{m}^{2}$ every other week) is being expanded to further assess the safety and activity of the regimen [101].

\section{Panobinostat (LBH589)}

LBH589, a novel hydroxamate analog HDAC inhibitor, has been shown to induce acetylation of histone $\mathrm{H} 3$ and $\mathrm{H} 4$, increase p21 levels, disrupt the chaperone function of hsp90, and induce cell-cycle $\mathrm{G}_{1}$ phase accumulation and apoptosis of K562 cells and acute leukemia MV4-11 cells [102]. The anti-tumor effect by LBH589 was also demonstrated in multiple myeloma, NSCLC as well as castrate-resistant prostate cancer cell lines [30,103-107].

The first clinical trial was done in the patients with hematological malignancy. LBH589 was administered intravenously as a 30-minute infusion on days 1 to 7 of a 21-day cycle (Table 3). Fifteen patients with AML, acute lymphocytic leukemia (ALL), or MDS were treated with LBH589 at the following dose levels $\left(\mathrm{mg} / \mathrm{m}^{2}\right): 4.8$ to 14 . The DLTs (grade $3 \mathrm{QTcF}$ prolongation) were observed in four at $14.0 \mathrm{mg} / \mathrm{m}^{2}$. QTcF prolongation was asymptomatic and reversed on LBH589 discontinuation. Other potentially LBH589-related toxicities included nausea (40\%), diarrhea (33\%), vomiting (33\%), hypokalemia (27\%), loss of appetite (13\%), and thrombocytopenia (13\%). In 8 of 11 patients with peripheral blasts, transient blast cell reductions occurred with a rebound following the 7-day treatment period. $\mathrm{H} 3$ and $\mathrm{H} 2 \mathrm{~B}$ acetylation increase was significant in B-cells and blasts. Intravenous administration of LBH589 was well tolerated at doses $<11.5 \mathrm{mg} / \mathrm{m}^{2}$ with consistent antileukemic and biological effects [108].

The patients with CTCL (stage IB-IVA) were enrolled in an open-label clinical trial study to measure the safety and toxicity of LBH589. Patients included Mycosis fungoides (MF) and Sezary syndrome (SS), who have failed $\geq 2$ prior systemic therapies. Patients were assigned to two different groups: Group 1 previously treated with oral bexarotene or Group 2 without bexarotene. Panobinostat $(20 \mathrm{mg}$ ) was administered orally on days 1 , 3, and 5 weekly until disease progression or intolerance. Most common ( $>15 \%)$ side effects include diarrhea, thrombocytopenia, fatigue, asthenia, hypertriglyceridaemia, dysgeusia, nausea and pruritus. Intensive ECG monitoring for QTc prolongation was performed. Among 1578 ECGs analyzed, there has been no QTc $>500 \mathrm{~ms}$, one QTc $>480 \mathrm{~ms}$, and one QTc $>60 \mathrm{~ms}$ increased from baseline. Best overall response is PR for 3 patients, SD for 4 patients. Preliminary safety data suggest that panobinostat is generally well tolerated [109]. Microarray data showed that panobinostat induced distinct gene expression profiles over time following treatment, with the majority of genes being repressed. Panobinostat regulated twenty-three common genes in all patients tested. A unique set of genes that can mediate biological responses such as apoptosis, immune regulation, and angiogenesis were commonly regulated in response to panobinostat. These genes are strong candidates for the future assessment of their functional role in mediating the anti-tumor responses of panobinostat [105].

HDAC inhibitors can block androgen receptor -mediated transcriptional activation of many genes and 
Table 3 Clinical studies of panobinostat (LBH589)

\begin{tabular}{|c|c|c|c|c|}
\hline Phase & Disease (pt. No.) & Schedule & Recommended dose $\&$ response & Reference \\
\hline । & $\begin{array}{l}\text { Relapsed or refractory AML } \\
(15), \text { MDS (1) and ALL(1). }\end{array}$ & Day 1 to 7 of a 21-day cycle & $11.5 \mathrm{mg} / \mathrm{m}^{2}$ & {$[108]$} \\
\hline । & $\begin{array}{l}\text { Cutaneous T-cell lymphoma } \\
\text { (9) }\end{array}$ & $\begin{array}{l}\text { Monday, Wednesday and Friday of each week on a } \\
\text { 28-day cycle }\end{array}$ & $\begin{array}{l}20 \mathrm{mg} \text { a day, } \\
\text { CR } 22.2 \% \text {, PR } 44.4 \% \text {, SD } 11.1 \% \text {, POD } \\
22.2 \%\end{array}$ & {$[105]$} \\
\hline । & $\begin{array}{l}\text { Castration-resistant prostate } \\
\text { cancer (16) }\end{array}$ & $\begin{array}{l}\text { Arm I: } 20 \mathrm{mg} \text { on } 1,3 \text { and } 5 \text { for } 2 \text { weeks on a 28-day } \\
\text { cycle; Arm II: } 15 \mathrm{mg} \text { on } 1,3 \text { and } 5 \text { for } 2 \text { weeks on a } \\
\text { 28-day cycle with docetaxel and prednisone }\end{array}$ & Arm I: POD 100\%; arm II: PR 37.5\% & [112] \\
\hline$\|$ & $\begin{array}{l}\text { Advanced CTCL(stage IB-IVA) } \\
\text { Group } 1 \text { previously treated } \\
\text { with bexarotene( } 25) \text {; group } \\
2 \text { bexarotene naïve(15) }\end{array}$ & $\begin{array}{l}\text { Days } 1,3 \text {, and } 5 \text { weekly until disease progression or } \\
\text { intolerance }\end{array}$ & $\begin{array}{l}\text { Group 1: } \\
\text { PR12\%, SD16\%, PD12\%;other patients } \\
\text { and most patients in groups have had } \\
\text { less than } 2 \text { months of follow-up. }\end{array}$ & [109] \\
\hline
\end{tabular}

thus may result in possible benefit in treating Castration-resistant prostate cancer [110]. Docetaxel is first line therapy for patient with castration-resistant prostate cancer [111]. Phase I Clinical study with oral panobinostat alone or in combination with docetaxel in castration-resistant prostate cancer showed that oral panobinostat with and without docetaxel is feasible and a drug-drug interaction is not apparent. 16 patients were enrolled in this study. DLTs include dyspnea and neutropenia. Three patients achieved a PR as best response. Two of these three patients elected to hold treatment due to fatigue. All evaluable patients at the 20 mg single agent dose (7/7) demonstrated accumulation of acetylated histones in monocytes [112].

\section{MGCD0103}

MGCD0103 is a novel isotype-selective inhibitor of human HDACs with the potential to regulate aberrant gene expression and restore normal growth control in malignancies. A phase I trial of MGCD0103, given as a three-times-per-week oral dose for 2 of every 3 weeks, was performed in patients with advanced solid tumors (Table 4). DLTs consisting of fatigue, nausea, vomiting, anorexia, and dehydration were observed in three (27\%) of 11 and two $(67 \%)$ of three patients treated at the 45 and $56 \mathrm{mg} / \mathrm{m}^{2} / \mathrm{d}$ dose levels, respectively. SD was observed after four or more cycles of treatments in five (16\%) of 32 patients assessable for efficacy. PK analyses demonstrated inter-patient variability which was improved by co-administration with low $\mathrm{pH}$ beverages. Elimination half-life ranged from 6.7 to 12.2 hours, and no accumulation was observed with repeated dosing. Pharmacodynamic (PD) evaluations confirmed inhibition of HDAC activity and induction of acetylation of $\mathrm{H} 3$ histones in peripheral WBCs from patients by MGCD0103. The recommended phase II dose was $45 \mathrm{mg} / \mathrm{m}^{2} /$ day. At doses evaluated, MGCD0103 appears to be tolerable and exhibits favorable PK and PD profiles with evidence of target inhibition in surrogate tissues [113].

MGCD0103 was also studied in patients with leukemia and MDS. Patients were treated with 3 times weekly schedule without interruption in this phase I study. The MTD was $60 \mathrm{mg} / \mathrm{m} 2$, with DLTs of fatigue, nausea, vomiting, and diarrhea observed at higher doses. Three patients achieved a complete bone marrow response. PK analyses indicated absorption of MGCD0103 within 1 hour and an elimination half-life in plasma of $9(+/-2)$ hours. In summary, MGCD0103 was well tolerated and had antileukemia activity [114].

MGCD0103 combined with gemcitabine had demonstrated more effective anti-tumor activity than alone in pre-clinical studies. Phase I/II study with MGCD0103 alone or combination with gemcitabine were done in patients with solid tumors recently. Phase I part of the trial studied adults with refractory solid tumors. Phase II part of the trial was limited to gemcitabine naive patients with locally advanced or metastatic pancreatic cancer. Patients received MGCD0103 (3 times a week) in 28-day cycles at sequential ascending doses using a 3 +3 design targeting a DLT rate of $<33 \%$. Gemcitabine was administered at $1,000 \mathrm{mg} / \mathrm{m}^{2}$, weekly $\times 3$ per cycle. DLTs included fatigue, vomiting and abdominal pain as well as thrombocytopenia and anemia. Inhibition of HDAC activity was observed in patients' PBMCs. The MTD and recommended phase II dose was $90 \mathrm{mg}$. Among 14 response-evaluable phase I patients, there were 2 PRs out of 5 pancreatic carcinoma patients and 2 PRs in a patient with nasopharyngeal cancer and a patient with cutaneous T- cell lymphoma. Two patients were observed with SD after receiving $>2$ cycles (1 lung and 1 pancreatic). The combination may have clinical activity in patients with solid tumors in general and pancreatic cancer in particular. Phase II at the dose of $90 \mathrm{mg}$ of MGCD0103 is ongoing in patients with pancreatic cancer [115].

Open-label, phase II trial in adults with relapsed or refractory diffuse large B-cell lymphoma (DLBCL) or follicular lymphoma (FL) also demonstrated significant anti-cancer activity with manageable side effect profile. Fifty patients received treatment; including 33 DLBCL and $17 \mathrm{FL}$. Of 17 DLBCL patients with tumor reassessed 
Table 4 Clinical studies of MGCD0103

\begin{tabular}{|c|c|c|c|c|c|}
\hline Phase & Other agent & Disease (pt. No.) & Schedule & Recommended dose $\&$ response & Reference \\
\hline 1 & & Advanced solid tumor(38) & $\begin{array}{l}\text { Three times per week for } 2 \text { of every } \\
\text { three weeks }\end{array}$ & $45 \mathrm{mg} / \mathrm{m}^{2} / \mathrm{d}$ & {$[113]$} \\
\hline । & & $\begin{array}{l}\text { Relapsed or refractory AML } \\
(22), M D S(5), A L L(1) \text { and } \\
C M L \text { (1) }\end{array}$ & $\begin{array}{l}\text { Three times weekly without } \\
\text { interruption }\end{array}$ & $60 \mathrm{mg} / \mathrm{m}^{2} / \mathrm{d}$ & [114] \\
\hline 1/ & Gemcitabine & Solid tumor(24/I and 4/II) & $\begin{array}{l}\text { Three times weekly for MGCD0103 and } \\
\text { weeklyX3 for Gemcitabine in 28-days } \\
\text { cycle }\end{array}$ & $\begin{array}{l}90 \mathrm{mg} / \mathrm{d} \text { and PR: } 40 \% \text { in } 2 \text { out of } 5 \\
\text { pancreatic carcinoma. }\end{array}$ & [115] \\
\hline$\|$ & & $\begin{array}{l}\text { Relapsed or refractory } \mathrm{NHL} \\
\text { ( } 33 \text { of } \mathrm{DLBCL} \text { and } 17 \text { of } \mathrm{FL} \text { ) }\end{array}$ & $\begin{array}{l}\text { Three times weekly without } \\
\text { interruption }\end{array}$ & $\begin{array}{l}\text { Started } 110 \mathrm{mg} \text {, then decreased to } 85 \\
\mathrm{mg} \text {. RR for DLBCL } 23.5 \% \text { and } P R \text { for } F L \\
10 \% \text {. }\end{array}$ & [116] \\
\hline$\|$ & & Relapsed or refractory $\mathrm{HL}(33)$ & Three times weekly in 28 days cycle & $\begin{array}{l}85 \mathrm{mg} \text { or } 110 \mathrm{mg} \\
\text { OR } 38 \% \text {. }\end{array}$ & {$[117]$} \\
\hline
\end{tabular}

by $\mathrm{CT}$, most had tumor reduction, including $1 \mathrm{CR} \& 3$ PRs, with progression free survival (PFS) for responders ranging from 168 to $>336$ days. Five DLBCL patients with stable disease had PFS ranging from 112 to $>336$ days. One of $10 \mathrm{FL}$ patients achieved PR. The most common toxicities of grade $\geq 3$ were fatigue (14\%), neutropenia (12\%), thrombocytopenia (10\%), and anemia (6\%) [116].

Since Hodgkin's lymphoma (HL) patients with relapsed or refractory disease have poor prognosis, an open-label, phase II trial in adults with relapsed/refractory HL was conducted. Patients received MGCD0103 at 110 or $85 \mathrm{mg} 3$ times per week in 4-week cycles. Among 23 patients in the $110 \mathrm{mg}$ cohort, 21 were evaluated, of whom $2(10 \%)$ had CRs and 6 (29\%) had PRs for an ORR of $38 \%$. The 2 patients with CRs had progression free survival lasting $>270$ and $>420$ days, respectively, with both responses ongoing. One additional patient (5\%) had SD >6 cycles. Among 10 patients in the $85 \mathrm{mg}$ cohort, 5 were evaluated for efficacy, all of whom had tumor reductions of $\geq 30 \%$; including $1 \mathrm{PR}$ and 2 SDs. MGCD0103 demonstrated significant antitumor activity in relapsed/refractory HL [117].

\section{Belinostat (PXD101)}

The activity of belinostat was investigated in many cell lines, which include hepatocellular carcinoma, human cancer, chronic lymphocytic leukemia, prostate cancer, bladder cancer, head and neck squamous carcinomas and ovarian cancer cells in preclinical studies [118-126].

In a phase I clinical trial, forty-six patients with advanced refractory solid tumors received belinostat at one of six dose levels $\left(150-1200 \mathrm{mg} / \mathrm{m}^{2} / \mathrm{d}\right)$. DLTs were fatigue, diarrhea, atrial fibrillation; and grade 2 nausea/ vomiting leading to inability to complete a full 5 -day cycle. The MTD was $1000 \mathrm{mg} / \mathrm{m} 2 / \mathrm{d}$. The intermediate elimination half-life was 0.3 to $1.3 \mathrm{~h}$ and was independent of dose. SD was observed in a total of 18 (39\%) patients, including 15 treated for more than 4 cycles. Of the 24 patients treated at the MTD, 50\% achieved SD.
Belinostat exhibits dose-dependent pharmacodynamic effects, and has promising anti-tumor activity (Table 5) [127].

Sixteen patients with advanced hematological neoplasms received belinostat in another clinical trial at one of three dose levels: $600 \mathrm{mg} / \mathrm{m}^{2} / \mathrm{d}, 900 \mathrm{mg} / \mathrm{m}^{2} / \mathrm{d}$ and $1000 \mathrm{mg} / \mathrm{m}^{2} / \mathrm{d}$. The most common treatment-related adverse events were nausea, vomiting, fatigue and flushing. No grade 3 or 4 hematological toxicity compared with baseline occurred except one case of grade 3 lymphopenia. There were two grade 4 renal failure. Both events occurred in patients with multiple myeloma. No cardiac events were noted. No CRs or PRs were noted in these heavily pre-treated patients. However, five patients, including two patients with diffuse large-cell lymphoma achieved SD after two to nine treatment cycles. Intravenous belinostat at 600, 900 and $1000 \mathrm{mg} /$ $\mathrm{m}^{2} / \mathrm{d}$ was well tolerated. $1000 \mathrm{mg} / \mathrm{m}^{2} / \mathrm{d}$ on days $1-5$ in a 21-d cycle was recommended for phase II studies in patients with hematological neoplasia [128].

Simultaneously targeting two epigenetic pathways using belinostat and the DNA hypomethylating agent azacitidine (AZA) may lead to an additive or synergistic effect in patients with advanced myeloid neoplasms. AZA, $75 \mathrm{mg} / \mathrm{m}^{2} / \mathrm{d}$, was given subcutaneously on days 1 5 followed by escalating doses of belinostat given intravenously over 30 minutes on the same days in a 28 day cycle. Twenty one patients received at least 1 cycle and are evaluated for response: 2 CRs, 1 PR and 4 with hematologic improvement. Median time to response was 2 cycles. Increased platelets at 4 weeks were observed in one-third of patients at all dose levels studied. The combination of belinostat with AZA is feasible. A randomized study was suggested to further investigate the relative contribution of belinostat to clinical efficacy [129].

Patients with low malignant potential (LMP) ovarian tumors represent an understudied population whose tumors are intrinsically resistant to radiation and 
Table 5 Clinical studies of belinostat (PXD101)

\begin{tabular}{|c|c|c|c|c|c|}
\hline Phase & $\begin{array}{l}\text { Other } \\
\text { agent }\end{array}$ & Disease (pt. No.) & Schedule & Recommended dose $\&$ response & Reference \\
\hline । & & Advanced hematological neoplasms(16) & $\begin{array}{l}\text { Day } 1 \text { to } 5 \text { of a } 21- \\
\text { day cycle }\end{array}$ & $1000 \mathrm{mg} / \mathrm{m}^{2} / \mathrm{d}$ & {$[128]$} \\
\hline । & AZA & Advanced myeloid neoplasms(230 & $\begin{array}{l}\text { Days } 1-5 \text { of a } 28 \text { day } \\
\text { cycle }\end{array}$ & $1000 \mathrm{mg} / \mathrm{m}^{2}$ & [129] \\
\hline । & & Advanced refractory solid tumors(46) & $\begin{array}{l}\text { Days } 1-5 \text { of a } 21 \text { day } \\
\text { cycle }\end{array}$ & $\begin{array}{l}1000 \mathrm{mg} / \mathrm{m}^{2} \\
\text { SD } 39 \%\end{array}$ & [127] \\
\hline$\|$ & & relapsed malignant pleural mesothelioma(13) & $\begin{array}{l}\text { Days } 1-5 \text { of a } 21 \text { day } \\
\text { cycle }\end{array}$ & $\begin{array}{l}\text { Belinostat is not active as monotherapy } \\
\text { against recurrent malignant pleural } \\
\text { mesothelioma }\end{array}$ & [122] \\
\hline$\|$ & & $\begin{array}{l}\text { Platinum resistant epithelial ovarian tumors } \\
(E O C, 18) \text { and micropapillary/borderline ovarian } \\
\text { tumors(LMP,12) }\end{array}$ & $\begin{array}{l}\text { Days } 1-5 \text { of a } 21 \text { day } \\
\text { cycle with } 1000 \mathrm{mg} / \\
\mathrm{m} 2\end{array}$ & $\begin{array}{l}\text { EOC: SD 50\%, PD25\% N/E 25\%; LMP: SD } \\
75 \%, \text { PR8.3\%, N/E } 16.6 \%\end{array}$ & [130] \\
\hline
\end{tabular}

chemotherapy. Patients with platinum resistant epithelial ovarian cancer (EOC) have low response rates to conventional chemotherapy too. Belinostat demonstrates anti-tumor activity in ovarian cancer animal models. Two patient populations, metastatic or recurrent platinum resistant (<6 mo) EOC and LMP ovarian tumors, were enrolled to assess the activity of belinostat. Belinostat $1,000 \mathrm{mg} / \mathrm{m}^{2} /$ day was administered intravenously on days 1-5 of a 21 day cycle. The most frequent grade 3 adverse events were bowel obstruction, thrombosis, dyspnea, fatigue, lymphopenia, elevated ALP and nausea. Eighteen patients with EOC received a total of 50 cycles of treatment. 9 patients had SDs, 6 PODs, 3 are non evaluable and 2 remained on study. 12 patients with LMP tumors received 68 cycles of treatment. 1 patient had a PR, 9 SDs, and 2 are non evaluable. Belinostat showed promising activity in LMP ovarian tumors [130].

Thirteen patients with advanced mesothelioma with progression on one prior chemotherapy regimen have been recruited to a phase II study using belinostat. SD was seen in two patients. No objective responses were noted. One patient died as a consequence of cardiac arrhythmia. It was concluded that belinostat is not active as monotherapy against recurrent malignant pleural mesothelioma. Evaluation of combination strategies was suggested for further development of this novel agent in mesothelioma [122]

\section{Valproic acid}

Valproic acid (VPA) can induce in vitro differentiation of primary AML blasts in vitro. Seventy five patients with AML/MDS were enrolled in a clinical trial (Table 6). Of these, sixty six were started on VPA monotherapy, with later addition of all trans-retinoic acid (ATRA) in patients who did not respond or relapsed. Median treatment duration was 4 months for VPA and 2 months for ATRA. Hematological improvement was observed in 18 patients (24\%). Median response duration was 4 months. ATRA exerted no additional effect in patients receiving the combination. However, of ten VPA responders who relapsed, four achieved a second response after addition of ATRA. Response rates were strongly dependent on disease type according to WHO classification. There was a response rate of $52 \%$ in MDS patients with a normal blast count. The response rate was $6 \%$ in refractory anemia with excess blasts (I + II), $16 \%$ in AML, and $0 \%$ in chronic myelomonocytic leukemia [131]. Another clinical study in similar patient population showed that treatment with VPA/ATRA combination results in transient disease control in a subset of patients with AML that has evolved from a myeloproliferative disorder but not in patients with a primary or MDS-related AML [132,133]. In another study of 54 patients with AML/MDS, a fixed dose of decitabine ( $15 \mathrm{mg} / \mathrm{m}^{2}$ by IV daily for 10 days) was administered concomitantly with escalating doses of VPA orally for 10 days. A $50 \mathrm{mg} / \mathrm{kg}$ daily dose of VPA was found to be safe. Twelve (22\%) patients had objective response, including 10 (19\%) CRs, and 2 (3\%) CRs with incomplete platelet recovery. In summary, this combination of epigenetic therapy in leukemia appears to be safe and active, and was associated with transient reversal of aberrant epigenetic marks [134]. However, in a separate phase I study, encephalopathy was seen in AML patients treated with VPA plus Low-dose decitabine $\left(20 \mathrm{mg} / \mathrm{m}^{2} / \mathrm{d}\right.$ for 10 days) [135].

Soriano et al. conducted a phase I/II study of the combination of AZA, VPA, and ATRA in patients with AML or high-risk MDS. AZA was administered at a fixed dose of $75 \mathrm{mg} / \mathrm{m}^{2}$ daily for 7 days. VPA was doseescalated and given orally daily for 7 days concomitantly. ATRA was given at $45 \mathrm{mg} / \mathrm{m}^{2}$ orally daily for 5 days, starting on day 3. A total of 53 patients were treated. The MTD dose of VPA in this combination was 50 $\mathrm{mg} / \mathrm{kg}$ daily for 7 days. DLT was reversible neurotoxicity. The ORR was $42 \%$. Median remission duration was 26 weeks. In conclusion, the combination studied is safe and has significant clinical activity [136].

The activity of VPA was also evaluated on solid tumors. Twelve patients with cervical cancer were 
Table 6 Clinical studies of valproic acid

\begin{tabular}{|c|c|c|c|c|c|}
\hline Phase & Other agent & Disease (pt. No.) & Schedule & $\begin{array}{l}\text { Recommended dose \& } \\
\text { response }\end{array}$ & Reference \\
\hline । & $\begin{array}{l}\text { ATRA(80 mg/ } \\
\text { m2) }\end{array}$ & AML (58). & Twice a day & $\begin{array}{l}\text { VPA serum concentration to } \\
50-100 \mathrm{ug} / \mathrm{ml}\end{array}$ & [131] \\
\hline । & & Cervical cancer(12) & Once a day & $20-40 \mathrm{mg} / \mathrm{kg}$ & [137] \\
\hline । & $\begin{array}{l}\text { ATRA(45 mg/ } \\
\text { m2) }\end{array}$ & $\operatorname{AML}(26)$ & Once a day & $5-10 \mathrm{mg} / \mathrm{kg}$ & [132] \\
\hline । & $\begin{array}{l}\text { Decitabine (5 } \\
\mathrm{mg} / \mathrm{m} 2)\end{array}$ & NSCLC(8) & $\begin{array}{l}5 \text {-aza-CdR for } 10 \text { days in combination with VA on } \\
\text { days } 5-21 \text { of a } 28 \text {-day cycle. }\end{array}$ & $15 \mathrm{mg} / \mathrm{kg} / \mathrm{d}$ & [140] \\
\hline I & & $\begin{array}{l}\text { Refractory advanced } \\
\text { cancer(26) }\end{array}$ & Daily for 5 days in a 21-day cycle & $60 \mathrm{mg} / \mathrm{kg} /$ day & [138] \\
\hline । & Epirubicin & Solid tumor(44) & $\begin{array}{l}\text { Daily for three days then followed by epirubicin in } 21 \\
\text { day cycle }\end{array}$ & $\begin{array}{l}\text { VPA } 140 \mathrm{mg} / \mathrm{kg} / \mathrm{d} \\
\text { Epirubincin } 100 \mathrm{mg} / \mathrm{m} 2\end{array}$ & [139] \\
\hline | & AZA and ATRA & $\operatorname{AML}(49)$ and $M D S(4)$ & & VPA 75 mg/kg & [136] \\
\hline | and || & $\begin{array}{l}\text { Decitabine }(15 \\
\mathrm{mg} / \mathrm{m} 2)\end{array}$ & $\operatorname{AML}(54)$ & Once a day & $\begin{array}{l}50 \mathrm{mg} / \mathrm{kg}, 22 \% \text { objective } \\
\text { response }\end{array}$ & [134] \\
\hline
\end{tabular}

enrolled for phase I trial in 2005. The patients were treated with VPA after a baseline tumor biopsy and blood sampling at the following dose levels (four patients each): $20 \mathrm{mg} / \mathrm{kg} ; 30 \mathrm{mg} / \mathrm{kg}$, or $40 \mathrm{mg} / \mathrm{kg}$ for 5 days via oral route. At day 6 , tumor and blood sampling were repeated and the study protocol ended. Blood levels of VPA were measured at day 6 once the steadystate was reached. Mean daily dose for all patients was $1890 \mathrm{mg}$. Depressed level of consciousness of grade 2 was registered in nine patients. Serum levels of VPA ranged from 73.6-170.49 ug/mL. Tumor deacetylase activity decreased in eight patients with a statistically significant difference between pre and post-treatment values of HDAC activity ( $\mathrm{p}<0.0264$ ). No correlation between tumor hyperacetylation with serum levels of valproic acid was found [137]. Another phase I study in Twenty-six pre-treated patients with progressing solid tumors also showed that neurocognitive impairment dominated the toxicity profile, with grade 3 or 4 neurological side effects occurring in 8 out of 26 patients. No grade 3 or 4 hematological toxicity was observed. The MTD of infusion VPA was $60 \mathrm{mg} \mathrm{kg} /$ day. Further investigations are warranted to evaluate the effect of VPA alone and in combination with other cytotoxic drugs [138].

In another phase I study, a sequence-specific combination of VPA and epirubicin in solid tumor malignancies was done. Patients were treated with increasing doses of VPA for three days followed by epirubicin in 3-week cycles. The study evaluated PK and PD end points, toxicities, and tumor response. DLTs were similar to that seen with single agent VPA. No exacerbation of epirubicin-related toxicities was observed. The MTD and recommended phase II dose was VPA $140 \mathrm{mg} / \mathrm{kg} / \mathrm{d}$ for 48 hours followed by epirubicin $100 \mathrm{mg} / \mathrm{m}^{2}$. PRs were seen across different tumor types in nine patients (22\%), and SDs were seen in 16 patients (39\%). Anti-tumor activity was observed in heavily pretreated patients and historically anthracycline-resistant tumors [139]. In another phase I study in patient with metastatic NSCLC, combination of decitabine at dose $5 \mathrm{mg} / \mathrm{m}^{2}$ for 10 days with VPA at $10 \mathrm{mg} / \mathrm{kg} / \mathrm{d}$ on days $5-21$ of a 28 day cycle was not well tolerated. Further study of decitabine at a five day schedule in combination with HDAC inhibitors is ongoing $[139,140]$.

A phase II study of hydralazine and VPA in treating patients with advanced solid tumors revealed clinical benefit. Primary tumor included cervix (3), breast (3), lung (1), testis (1), and ovarian (7) carcinomas. Clinical benefit was observed in 12 (80\%) patients: four PRs, and eight SDs. The most significant toxicity was hematological [141].

\section{Conclusions}

Targeted therapy is widely used nowadays for cancer treatment. The targeting agents include inhibitors of tyrosine kinases, angiogenesis, mTOR, and epigenetic pathways, to name a few [142-145]. Besides vorinostat, there are more than 8 other HDAC inhibitors undergoing active clinical investigation. It is noteworthy that ITF2357 showed significant anti-HL activity. Panobinostat showed consistent anti-leukemic effects. Belinostat appears to be promising for treating LMP ovarian tumor. The combination of AZA, VPA, and ATRA has significant clinical activity in leukemia and MDS. Epigenetic agents in combination regimens for cancer therapy are being actively studied.

\section{Abbreviations}

AML: Acute myeloid leukemia; ALL: Acute lymphocyte leukemia; AR: Androgen receptor; ATRA: All-trans retinoic acid; CLL: Chronic lymphocyte leukemia; CML-BC: Chronic myeloid leukemia blast crisis; CR: Complete response; CTCL: Cutaneous T-cell lymphoma; DLBCL: Diffuse large B-cell lymphoma; DLTs: Dose-limiting toxicities; DNMT: DNA methyltransferase; EOC: Epithelial ovarian cancer; FL: Follicular lymphoma; HDACs: Histone 
deacetylases; HL: Hodgkin lymphoma; LMP: Low malignant potential; MF: Mycosis fungoides; MDS: Myelodysplastic syndrome; MTD: Maximum tolerated dose; NHL: Non Hodgkin lymphoma; NSCLC: Non small cell lung carcinoma; ORR: Overall response rate; PBMCs: Peripheral blood mononuclear cells; PD: Pharmacodynamic: Progression free survival; PK: Pharmacokinetics; POD: Progression of disease; PR: Partial response; RAl: Radioactive iodine; SAHA: Suberoyl anilide hydroxamic acid; SD: Stabilization of disease; SS: Sezary syndrome.

\section{Acknowledgements}

Shundong Cang and Yuehua Ma are CAHON (CAHON.ORG) Research Scholars and recipients of fellowship grants from the International Scholar Exchange Foundation. This work was partly supported by New York Medical College Blood Diseases Fund.

\section{Author details}

'Department of Medicine, The Mount Vernon Hospital, Mount Vernon, NY, 10550, USA. ${ }^{2}$ Department of Oncology, Henan Province People's Hospital, Zhengzhou, China. ${ }^{3}$ Division of Oncology/Hematology, New York Medical College, Valhalla, NY 10595, USA.

\section{Authors' contributions}

JT and $\mathrm{DL}$ are involved in concept design. All authors participated in data collection, drafting and critically revising the manuscript.

\section{Competing interests}

The authors declare that they have no competing interests.

Received: 15 December 2009

Accepted: 4 February 2010 Published: 4 February 2010

\section{References}

1. Kornberg RD, Lorch Y: Twenty-five years of the nucleosome, fundamental particle of the eukaryote chromosome. Cell 1999, 98:285-294.

2. Luger K: Dynamic nucleosomes. Chromosome Res 2006, 14:5-16.

3. Luger K, Hansen JC: Nucleosome and chromatin fiber dynamics. Curr Opin Struct Biol 2005, 15:188-196.

4. Luger K: Structure and dynamic behavior of nucleosomes. Curr Opin Genet Dev 2003, 13:127-135.

5. Duncan EM, Muratore-Schroeder TL, Cook RG, Garcia BA, Shabanowitz J, Hunt DF, et al: Cathepsin L proteolytically processes histone H3 during mouse embryonic stem cell differentiation. Cell 2008, 135:284-294.

6. Glaser KB: HDAC inhibitors: clinical update and mechanism-based potential. Biochem Pharmacol 2007, 74:659-671.

7. Zheng YG, Wu J, Chen Z, Goodman M: Chemical regulation of epigenetic modifications: opportunities for new cancer therapy. Med Res Rev 2008, 28:645-687.

8. Strietholt S, Maurer B, Peters MA, Pap T, Gay S: Epigenetic modifications in rheumatoid arthritis. Arthritis Res Ther 2008, 10:219.

9. Berger SL: An embarrassment of niches: the many covalent modifications of histones in transcriptional regulation. Oncogene 2001, 20:3007-3013.

10. Lin HY, Chen CS, Lin SP, Weng JR, Chen CS: Targeting histone deacetylase in cancer therapy. Med Res Rev 2006, 26:397-413.

11. Fukuda H, Sano N, Muto S, Horikoshi M: Simple histone acetylation plays a complex role in the regulation of gene expression. Brief Funct Genomic Proteomic 2006, 5:190-208.

12. Hess-Stumpp H: Histone deacetylase inhibitors and cancer: from cell biology to the clinic. Eur J Cell Biol 2005, 84:109-121.

13. Cang S, Ma Y, Liu D: New clinical developments in histone deacetylase inhibitors for epigenetic therapy of cancer. Journal of Hematology \& Oncology 2009, 2:22.

14. Gallinari P, Di MS, Jones P, Pallaoro M, Steinkuhler C: HDACs, histone deacetylation and gene transcription: from molecular biology to cancer therapeutics. Cell Res 2007, 17:195-211.

15. Brosch G, Loidl P, Graessle S: Histone modifications and chromatin dynamics: a focus on filamentous fungi. FEMS Microbiol Rev 2008, 32:409-439.

16. Gregoretti IV, Lee YM, Goodson HV: Molecular evolution of the histone deacetylase family: functional implications of phylogenetic analysis. $J$ Mol Biol 2004, 338:17-31.
17. Fischle $W$, Kiermer V, Dequiedt $F$, Verdin E: The emerging role of class II histone deacetylases. Biochem Cell Biol 2001, 79:337-348.

18. Yang XJ, Gregoire S: Class II histone deacetylases: from sequence to function, regulation, and clinical implication. Mol Cell Biol 2005, 25:2873-2884.

19. de Ruijter AJ, van Gennip AH, Caron HN, Kemp S, van Kuilenburg AB: Histone deacetylases (HDACs): characterization of the classical HDAC family. Biochem J 2003, 370:737-749.

20. Gao L, Cueto MA, Asselbergs F, Atadja P: Cloning and functional characterization of HDAC11, a novel member of the human histone deacetylase family. J Biol Chem 2002, 277:25748-25755.

21. Marks P, Rifkind RA, Richon VM, Breslow R, Miller T, Kelly WK: Histone deacetylases and cancer: causes and therapies. Nat Rev Cancer 2001, 1:194-202.

22. Bieliauskas AV, Pflum MK: Isoform-selective histone deacetylase inhibitors. Chem Soc Rev 2008, 37:1402-1413.

23. Papeleu P, Vanhaecke T, Elaut $G$, Vinken $M$, Henkens $T$, Snykers $S$, et al: Differential effects of histone deacetylase inhibitors in tumor and normal cells-what is the toxicological relevance?. Crit Rev Toxicol 2005, 35:363-378.

24. Yoshida M, Matsuyama A, Komatsu Y, Nishino N: From discovery to the coming generation of histone deacetylase inhibitors. Curr Med Chem 2003, 10:2351-2358.

25. Kouraklis $\mathrm{G}$, Theocharis $\mathrm{S}$ : Histone deacetylase inhibitors and anticancer therapy. Curr Med Chem Anticancer Agents 2002, 2:477-484.

26. Walkinshaw DR, Yang XJ: Histone deacetylase inhibitors as novel anticancer therapeutics. Curr Oncol 2008, 15:237-243.

27. Dokmanovic M, Marks PA: Prospects: histone deacetylase inhibitors. J Cell Biochem 2005, 96:293-304.

28. Coffey DC, Kutko MC, Glick RD, Swendeman SL, Butler L, Rifkind R, et al: Histone deacetylase inhibitors and retinoic acids inhibit growth of human neuroblastoma in vitro. Med Pediatr Oncol 2000, 35:577-581.

29. Coffey DC, Kutko MC, Glick RD, Butler LM, Heller G, Rifkind RA, et al: The histone deacetylase inhibitor, $\mathrm{CBHA}$, inhibits growth of human neuroblastoma xenografts in vivo, alone and synergistically with alltrans retinoic acid. Cancer Res 2001, 61:3591-3594.

30. Edwards A, Li J, Atadja P, Bhalla K, Haura EB: Effect of the histone deacetylase inhibitor LBH589 against epidermal growth factor receptordependent human lung cancer cells. Mol Cancer Ther 2007, 6:2515-2524.

31. Maiso P, Carvajal-Vergara X, Ocio EM, Lopez-Perez R, Mateo G, Gutierrez N, et al: The histone deacetylase inhibitor LBH589 is a potent antimyeloma agent that overcomes drug resistance. Cancer Res 2006, 66:5781-5789.

32. Scuto A, Kirschbaum M, Kowolik C, Kretzner L, Juhasz A, Atadja P, et al: The novel histone deacetylase inhibitor, LBH589, induces expression of DNA damage response genes and apoptosis in $\mathrm{Ph}$ - acute lymphoblastic leukemia cells. Blood 2008, 111:5093-5100.

33. Trus MR, Yang L, Suarez SF, Bordeleau L, Jurisica I, Minden MD: The histone deacetylase inhibitor valproic acid alters sensitivity towards all trans retinoic acid in acute myeloblastic leukemia cells. Leukemia 2005, 19:1161-1168

34. Morotti A, Cilloni D, Messa F, Arruga F, Defilippi I, Carturan S, et al: Valproate enhances imatinib-induced growth arrest and apoptosis in chronic myeloid leukemia cells. Cancer 2006, 106:1188-1196.

35. Camphausen K, Cerna D, Scott T, Sproull M, Burgan WE, Cerra MA, et al: Enhancement of in vitro and in vivo tumor cell radiosensitivity by valproic acid. Int I Cancer 2005, 114:380-386.

36. Gottlicher M: Valproic acid: an old drug newly discovered as inhibitor of histone deacetylases. Ann Hematol 2004, 83(Suppl 1):S91-S92.

37. De $S H$, Kimpe $M$, Isebaert $S$, Nuyts $S$ : A systematic assessment of radiation dose enhancement by 5 -Aza-2'-deoxycytidine and histone deacetylase inhibitors in head-and-neck squamous cell carcinoma. Int I Radiat Oncol Biol Phys 2009, 73:904-912.

38. Jung M: Inhibitors of histone deacetylase as new anticancer agents. Curr Med Chem 2001, 8:1505-1511.

39. Qu W, Kang YD, Zhou MS, Fu LL, Hua ZH, Wang LM: Experimental study on inhibitory effects of histone deacetylase inhibitor MS-275 and TSA on bladder cancer cells. Urol Oncol 2009

40. Camphausen K, Scott T, Sproull M, Tofilon PJ: Enhancement of xenograft tumor radiosensitivity by the histone deacetylase inhibitor MS-275 and correlation with histone hyperacetylation. Clin Cancer Res 2004, 10:6066-6071. 
41. Singh TR, Shankar S, Srivastava RK: HDAC inhibitors enhance the apoptosis-inducing potential of TRAIL in breast carcinoma. Oncogene 2005, 24:4609-4623.

42. Bonfils C, Kalita A, Dubay M, Siu LL, Carducci MA, Reid G, et al: Evaluation of the pharmacodynamic effects of MGCD0103 from preclinical models to human using a novel HDAC enzyme assay. Clin Cancer Res 2008, 14:3441-3449.

43. Le TC, Siu LL: Promising antitumor activity with MGCD a novel isotypeselective histone deacetylase inhibitor. Expert Opin Investig Drugs 0103 , 17:1247-1254.

44. Zhou N, Moradei O, Raeppel S, Leit S, Frechette S, Gaudette F, et al: Discovery of N-(2-aminophenyl)-4-[(4-pyridin-3-ylpyrimidin-2-ylamino) methyl]benzamide (MGCD0103), an orally active histone deacetylase inhibitor. J Med Chem 2008, 51:4072-4075.

45. Khan N, Jeffers M, Kumar S, Hackett C, Boldog F, Khramtsov N, et al: Determination of the class and isoform selectivity of small-molecule histone deacetylase inhibitors. Biochem J 2008, 409:581-589.

46. Piekarz RL, Robey R, Sandor V, Bakke S, Wilson WH, Dahmoush L, et al: Inhibitor of histone deacetylation, depsipeptide (FR901228), in the treatment of peripheral and cutaneous T-cell lymphoma: a case report. Blood 2001, 98:2865-2868.

47. Zhou W, Zhu WG: The changing face of HDAC inhibitor depsipeptide. Curr Cancer Drug Targets 2009, 9:91-100.

48. Murata M, Towatari M, Kosugi H, Tanimoto M, Ueda $R$, Saito $H$, et al: Apoptotic cytotoxic effects of a histone deacetylase inhibitor, FK228, on malignant lymphoid cells. Jpn J Cancer Res 2000, 91:1154-1160.

49. Konstantinopoulos PA, Vandoros GP, Papavassiliou AG: FK228 (depsipeptide): a HDAC inhibitor with pleiotropic antitumor activities. Cancer Chemother Pharmacol 2006, 58:711-715.

50. Sasakawa $Y$, Naoe $Y$, Inoue T, Sasakawa T, Matsuo M, Manda T, et al: Effects of FK228, a novel histone deacetylase inhibitor, on human lymphoma U937 cells in vitro and in vivo. Biochem Pharmacol 2002, 64:1079-1090.

51. Balakin KV, Ivanenkov YA, Kiselyov AS, Tkachenko SE: Histone deacetylase inhibitors in cancer therapy: latest developments, trends and medicinal chemistry perspective. Anticancer Agents Med Chem 2007, 7:576-592.

52. Vigushin DM, Coombes RC: Histone deacetylase inhibitors in cancer treatment. Anticancer Drugs 2002, 13:1-13.

53. Mottet D, Castronovo V: Histone deacetylases: target enzymes for cancer therapy. Clin Exp Metastasis 2008, 25:183-189.

54. Shankar S, Srivastava RK: Histone deacetylase inhibitors: mechanisms and clinical significance in cancer: HDAC inhibitor-induced apoptosis. Adv Exp Med Biol 2008, 615:261-298.

55. Witt O, Deubzer HE, Lodrini M, Milde T, Oehme I: Targeting histone deacetylases in neuroblastoma. Curr Pharm Des 2009, 15:436-447.

56. Martinez-Iglesias O, Ruiz-Llorente L, Sanchez-Martinez R, Garcia L, Zambrano A, Aranda A: Histone deacetylase inhibitors: mechanism of action and therapeutic use in cancer. Clin Trans/ Oncol 2008, 10:395-398.

57. Marks PA, Dokmanovic M: Histone deacetylase inhibitors: discovery and development as anticancer agents. Expert Opin Investig Drugs 2005, 14:1497-1511.

58. Glaser KB, Li J, Pease LJ, Staver MJ, Marcotte PA, Guo J, et al: Differential protein acetylation induced by novel histone deacetylase inhibitors. Biochem Biophys Res Commun 2004, 325:683-690.

59. Pan LN, Lu J, Huang B: HDAC inhibitors: a potential new category of antitumor agents. Cell Mol Immunol 2007, 4:337-343.

60. Bannister AJ, Zegerman P, Partridge JF, Miska EA, Thomas JO, Allshire RC, et al: Selective recognition of methylated lysine 9 on histone $\mathrm{H} 3$ by the HP1 chromo domain. Nature 2001, 410:120-124.

61. Jones DO, Cowell IG, Singh PB: Mammalian chromodomain proteins: their role in genome organisation and expression. Bioessays 2000, 22:124-137.

62. Lachner M, O'Carroll D, Rea S, Mechtler $K$, Jenuwein T: Methylation of histone H3 lysine 9 creates a binding site for HP1 proteins. Nature 2001, 410:116-120.

63. Carrozza MJ, Utley RT, Workman JL, Cote J: The diverse functions of histone acetyltransferase complexes. Trends Genet 2003, 19:321-329.

64. Boyes J, Byfield P, Nakatani Y, Ogryzko V: Regulation of activity of the transcription factor GATA-1 by acetylation. Nature 1998, 396:594-598

65. Huo X, Zhang J: Important roles of reversible acetylation in the function of hematopoietic transcription factors. J Cell Mol Med 2005, 9:103-112.

66. Mariadason JM: HDACs and HDAC inhibitors in colon cancer. Epigenetics 2008, 3:28-37.
67. Sano $Y$, Ishii S: Increased affinity of c-Myb for CREB-binding protein (CBP) after CBP-induced acetylation. J Biol Chem 2001, 276:3674-3682.

68. Glozak MA, Sengupta N, Zhang X, Seto E: Acetylation and deacetylation of non-histone proteins. Gene 2005, 363:15-23.

69. Budillon A, Di GE, Bruzzese F, Rocco M, Manzo G, Caraglia M: Histone deacetylase inhibitors: a new wave of molecular targeted anticancer agents. Recent Patents Anticancer Drug Discov 2007, 2:119-134.

70. Fiskus W, Rao R, Fernandez P, Herger B, Yang Y, Chen J, et al: Molecular and biologic characterization and drug sensitivity of pan-histone deacetylase inhibitor-resistant acute myeloid leukemia cells. Blood 2008, 112:2896-2905

71. Fiskus W, Ren Y, Mohapatra A, Bali P, Mandawat A, Rao R, et al: Hydroxamic acid analogue histone deacetylase inhibitors attenuate estrogen receptor-alpha levels and transcriptional activity: a result of hyperacetylation and inhibition of chaperone function of heat shock protein 90. Clin Cancer Res 2007, 13:4882-4890.

72. Catalano MG, Poli R, Pugliese M, Fortunati N, Boccuzzi G: Valproic acid enhances tubulin acetylation and apoptotic activity of paclitaxel on anaplastic thyroid cancer cell lines. Endocr Relat Cancer 2007, 14:839-845.

73. Simms-Waldrip T, Rodriguez-Gonzalez A, Lin T, Ikeda AK, Fu C, Sakamoto KM: The aggresome pathway as a target for therapy in hematologic malignancies. Mol Genet Metab 2008, 94:283-286.

74. Siegel D, Hussein M, Belani C, Robey R, Galanis F, Richon VM, et al: Vorinostat in solid and hematologic malignancies. J Hematol Oncol 2009, 2:27.

75. Buggy JJ, Cao ZA, Bass KE, Verner E, Balasubramanian S, Liu L, et al: CRA024781: a novel synthetic inhibitor of histone deacetylase enzymes with antitumor activity in vitro and in vivo. Mol Cancer Ther 2006, 5:1309-1317.

76. Banuelos CA, Banath JP, MacPhail SH, Zhao J, Reitsema T, Olive PL: Radiosensitization by the histone deacetylase inhibitor PCI-24781. Clin Cancer Res 2007, 13:6816-6826.

77. Adimoolam S, Sirisawad M, Chen J, Thiemann P, Ford JM, Buggy JJ: HDAC inhibitor PCl-24781 decreases RAD51 expression and inhibits homologous recombination. Proc Natl Acad Sci USA 2007, 104:19482-19487.

78. Undevia SD, Janisch L, Schilsky RL, Loury D, Balasubramanian S, Mani C, et al: Phase I study of the safety, pharmacokinetics (PK) and pharmacodynamics (PD) of the histone deacetylase inhibitor (HDACi) PCl-24781. J Clin Oncol 2008, 26(suppl):abstr 14514, abstr \#14514.

79. Barbetti V, Gozzini A, Rovida E, Morandi A, Spinelli E, Fossati G, et al: Selective anti-leukaemic activity of low-dose histone deacetylase inhibitor ITF2357 on AML1/ETO-positive cells. Oncogene 2008, 27:1767-1778.

80. Petrini M, Galimberti S, Canestraro M, Savli H, Palumbo GA, Nagy B: Histone deacetylase inhibitor ITF2357 is effective on the P39 cells. A gene expression study. J Clin Oncol 2008, 26(32):5156-5164.

81. Savli H, Galimberti S, Canestraro M, Nagy B, Palumbo GA, Petrini M: Bortezomib combined with histone deacetylase inhibitor ITF2357 or arsenic trioxide exerts aynergistic anti-proliferative and pro-apoptotic effect on P39 cells. J Clin Oncol 2008, 26(Suppl):18022.

82. Guerini V, Barbui V, Spinelli O, Salvi A, Dellacasa C, Carobbio A, et al: The histone deacetylase inhibitor ITF2357 selectively targets cells bearing mutated JAK2(V617F). Leukemia 2008, 22:740-747.

83. Golay J, Cuppini L, Leoni F, Mico C, Barbui V, Domenghini M, et al: The histone deacetylase inhibitor ITF2357 has anti-leukemic activity in vitro and in vivo and inhibits IL-6 and VEGF production by stromal cells. Leukemia 2007, 21:1892-1900.

84. Viviani S, Bonfante V, Fasola C, Valagussa P, Gianni AM: Phase II study of the histone-deacetylase inhibitor ITF2357 in relapsed/refractory Hodgkin's lymphoma patients. J Clin Oncol 2008, 26(suppl; ):abstr 8532

85. Hess-Stumpp H, Bracker TU, Henderson D, Politz O: MS-275, a potent orally available inhibitor of histone deacetylases-the development of an anticancer agent. Int J Biochem Cell Biol 2007, 39:1388-1405.

86. Lucas DM, Davis ME, Parthun MR, Mone AP, Kitada S, Cunningham KD, et al: The histone deacetylase inhibitor MS-275 induces caspase-dependent apoptosis in B-cell chronic lymphocytic leukemia cells. Leukemia 2004, 18:1207-1214.

87. Rosato RR, Almenara JA, Grant S: The histone deacetylase inhibitor MS275 promotes differentiation or apoptosis in human leukemia cells through a process regulated by generation of reactive oxygen species and induction of p21CIP1/WAF1 1. Cancer Res 2003, 63:3637-3645. 
88. Marks P, Rifkind RA, Richon VM, Breslow R, Miller T, Kelly WK: Histone deacetylases and cancer: causes and therapies. Nat Rev Cancer 2001, 1:194-202.

89. Ryan QC, Headlee D, Acharya M, Sparreboom A, Trepel JB, Ye J, et al: Phase I and pharmacokinetic study of MS-275, a histone deacetylase inhibitor, in patients with advanced and refractory solid tumors or lymphoma. J Clin Oncol 2005, 23:3912-3922.

90. Kummar S, Gutierrez M, Gardner ER, Donovan E, Hwang K, Chung EJ, et al: Phase I trial of MS-275, a histone deacetylase inhibitor, administered weekly in refractory solid tumors and lymphoid malignancies. Clin Cancer Res 2007, 13:5411-5417.

91. Gore L, Rothenberg ML, O'Bryant CL, Schultz MK, Sandler AB, Coffin D, et al: A phase I and pharmacokinetic study of the oral histone deacetylase inhibitor, MS-275, in patients with refractory solid tumors and lymphomas. Clin Cancer Res 2008, 14:4517-4525.

92. Gojo I, Jiemjit A, Trepel JB, Sparreboom A, Figg WD, Rollins S, et al: Phase 1 and pharmacologic study of MS-275, a histone deacetylase inhibitor, in adults with refractory and relapsed acute leukemias. Blood 2007, 109:2781-2790

93. Juergens RA, Vendetti F, Coleman B, Sebree RS, Rudek MA, Belinsky SA: Phase I trial of 5-azacitidine (5AC) and SNDX-275 in advanced lung cancer (NSCLC). J Clin Oncol 2008, 26:abstr \#19036..

94. Sandor V, Bakke S, Robey RW, Kang MH, Blagosklonny MV, Bender J, et al: Phase I trial of the histone deacetylase inhibitor, depsipeptide (FR90 NSC 630176), in patients with refractory neoplasms. Clin Cancer Res 1228, 8:718-728.

95. Marshall JL, Rizvi N, Kauh J, Dahut W, Figuera M, Kang MH, et al: A phase I trial of depsipeptide (FR901228) in patients with advanced cancer. J Exp Ther Oncol 2002, 2:325-332.

96. Stadler WM, Margolin K, Ferber S, McCulloch W, Thompson JA: A phase II study of depsipeptide in refractory metastatic renal cell cancer. Clin Genitourin Cancer 2006, 5:57-60.

97. Schrump DS, Fischette MR, Nguyen DM, Zhao M, Li X, Kunst TF, et al: Clinical and molecular responses in lung cancer patients receiving Romidepsin. Clin Cancer Res 2008, 14:188-198.

98. Byrd JC, Marcucci G, Parthun MR, Xiao JJ, Klisovic RB, Moran M, et al: A phase 1 and pharmacodynamic study of depsipeptide (FK228) in chronic lymphocytic leukemia and acute myeloid leukemia. Blood 2005, 105:959-967.

99. Klimek VM, Fircanis S, Maslak P, Guernah I, Baum M, Wu N, et al: Tolerability, pharmacodynamics, and pharmacokinetics studies of depsipeptide (romidepsin) in patients with acute myelogenous leukemia or advanced myelodysplastic syndromes. Clin Cancer Res 2008, 14:826-832.

100. Piekarz R, Luchenko V, Draper D, Wright JJ, Figg WD, Fojo AT, et al: Phase I trial of romidepsin, a histone deacetylase inhibitor, given on days one, three and five in patients with thyroid and other advanced cancers. J Clin Oncol 2008, 26:abstr 3571.

101. Doss HH, Jones SF, Infante JR, Spigel DR, Willcutt N, Lamar R, et al: A phase I trial of romidepsin in combination with gemcitabine in patients with pancreatic and other advanced solid tumors. J Clin Oncol 2008, 26:abstr 2567.

102. George P, Bali P, Annavarapu S, Scuto A, Fiskus W, Guo F, et al: Combination of the histone deacetylase inhibitor LBH589 and the hsp90 inhibitor 17-AAG is highly active against human CML-BC cells and AML cells with activating mutation of FLT-3. Blood 2005, 105:1768-1776.

103. Bali P, Pranpat M, Bradner J, Balasis M, Fiskus W, Guo F, et al: Inhibition of histone deacetylase 6 acetylates and disrupts the chaperone function of heat shock protein 90: a novel basis for antileukemia activity of histone deacetylase inhibitors. J Biol Chem 2005, 280:26729-26734.

104. Haefner M, Bluethner T, Niederhagen M, Moebius C, Wittekind C, Mossner J, et al: Experimental treatment of pancreatic cancer with two novel histone deacetylase inhibitors. World J Gastroenterol 2008, 14:3681-3692.

105. Ellis L, Pan Y, Smyth GK, George DJ, McCormack C, Williams-Truax R, et al: Histone deacetylase inhibitor panobinostat induces clinical responses with associated alterations in gene expression profiles in cutaneous Tcell lymphoma. Clin Cancer Res 2008, 14:4500-4510.

106. Qian DZ, Kato Y, Shabbeer S, Wei Y, Verheul HM, Salumbides B, et al: Targeting tumor angiogenesis with histone deacetylase inhibitors: the hydroxamic acid derivative LBH589. Clin Cancer Res 2006, 12:634-642.
107. Geng L, Cuneo KC, Fu A, Tu T, Atadja PW, Hallahan DE: Histone deacetylase (HDAC) inhibitor LBH589 increases duration of gamma$\mathrm{H} 2 \mathrm{AX}$ foci and confines HDAC4 to the cytoplasm in irradiated non-small cell lung cancer. Cancer Res 2006, 66:11298-11304.

108. Giles F, Fischer T, Cortes J, Garcia-Manero G, Beck J, Ravandi F, et al: A phase I study of intravenous LBH589, a novel cinnamic hydroxamic acid analogue histone deacetylase inhibitor, in patients with refractory hematologic malignancies. Clin Cancer Res 2006, 12:4628-4635.

109. Duvic M, Vanaclocha F, Bernengo MG, Okada C, Breneman D, Zinzani PL, et al: Phase II study of oral panobinostat (LBH589), a potent pandeacetylase inhibitor, in patients with refractory Cutaneous T-cell Lymphoma (CTCL). J Clin Oncol 2008, 26:abstr 8555.

110. Welsbie DS, Xu J, Chen Y, Borsu L, Scher HI, Rosen N, et al: Histone deacetylases are required for androgen receptor function in hormonesensitive and castrate-resistant prostate cancer. Cancer Res 2009, 69:958-966.

111. Beardsley EK, Chi KN: Systemic therapy after first-line docetaxel in metastatic castration-resistant prostate cancer. Curr Opin Support Palliat Care 2008, 2:161-166

112. Rathkopf DE, Wong BY, Ross RW, George DJ, Picus J, Tanaka E, et al: A phase I study of oral panobinostat (LBH589) alone and in combination with docetaxel (Doc) and prednisone in castration-resistant prostate cancer (CRPC). J Clin Oncol 2008, 26:abstr\# 5152.

113. Siu LL, Pili R, Duran I, Messersmith WA, Chen EX, Sullivan R, et al: Phase I study of MGCD0103 given as a three-times-per-week oral dose in patients with advanced solid tumors. J Clin Oncol 2008, 26:1940-1947.

114. Garcia-Manero G, Assouline S, Cortes J, Estrov Z, Kantarjian H, Yang H, et al: Phase 1 study of the oral isotype specific histone deacetylase inhibitor MGCD0103 in leukemia. Blood 2008, 112:981-989.

115. Hurwitz H, Nelson B, O'Dwyer PJ, Chiorean EG, Gabrail N, Li Z: Phase I/II: The oral isotype-selective HDAC inhibitor MGCD0103 in combination with gemcitabine (Gem) in patients (pts) with refractory solid tumors. $J$ Clin Oncol 2008, 26:abstr 4625

116. Crump M, Andreadis C, Assouline S, Rizzieri D, Wedgwood A, McLaughlin P: Treatment of relapsed or refractory non-hodgkin lymphoma with the oral isotype-selective histone deacetylase inhibitor MGCD0103: Interim results from a phase II study. J Clin Oncol 2008, 26:abstr\# 8528.

117. Bociek RG, Kuruvilla GJ, Pro B, Wedgwood A, Li Z: Isotype-selective histone deacetylase (HDAC) inhibitor MGCD0103 demonstrates clinical activity and safety in patients with relapsed/refractory classical Hodgkin Lymphoma (HL). J Clin Oncol 2008, 26:abstr 8507.

118. Buckley MT, Yoon J, Yee H, Chiriboga L, Liebes L, Ara G, et al: The histone deacetylase inhibitor belinostat (PXD101) suppresses bladder cancer cell growth in vitro and in vivo. J Transl Med 2007, 5:49.

119. Dai $Y$, Chen S, Kramer LB, Funk VL, Dent $P$, Grant S: Interactions between bortezomib and romidepsin and belinostat in chronic lymphocytic leukemia cells. Clin Cancer Res 2008, 14:549-558.

120. Dejligbjerg M, Grauslund M, Christensen IJ, Tjornelund J, Buhl JP, Sehested M: Identification of predictive biomarkers for the histone deacetylase inhibitor belinostat in a panel of human cancer cell lines. Cancer Biomark 2008, 4:101-109.

121. Duan J, Friedman J, Nottingham L, Chen Z, Ara G, Van WC: Nuclear factorkappaB p65 small interfering RNA or proteasome inhibitor bortezomib sensitizes head and neck squamous cell carcinomas to classic histone deacetylase inhibitors and novel histone deacetylase inhibitor PXD101. Mol Cancer Ther 2007, 6:37-50.

122. Ramalingam SS, Belani CP, Ruel C, Frankel P, Gitlitz B, Koczywas M, et al: Phase II study of belinostat (PXD101), a histone deacetylase inhibitor, for second line therapy of advanced malignant pleural mesothelioma. J Thorac Oncol 2009, 4:97-101.

123. Ma BB, Sung F, Tao Q, Poon FF, Lui WW, Yeo W, et al: The preclinical activity of the histone deacetylase inhibitor PXD101 (belinostat) in hepatocellular carcinoma cell lines. Invest New Drugs 2009.

124. Qian X, LaRochelle WJ, Ara G, Wu F, Petersen KD, Thougaard A, et al: Activity of PXD101, a histone deacetylase inhibitor, in preclinical ovarian cancer studies. Mol Cancer Ther 2006, 5:2086-2095.

125. Qian X, Ara G, Mills E, LaRochelle WJ, Lichenstein HS, Jeffers M: Activity of the histone deacetylase inhibitor belinostat (PXD101) in preclinical models of prostate cancer. Int J Cancer 2008, 122:1400-1410.

126. Kim JC, Kim DD, Lee YM, Kim TW, Cho DH, Kim MB, et al: Evaluation of novel histone deacetylase inhibitors as therapeutic agents for colorectal 
adenocarcinomas compared to established regimens with the histoculture drug response assay. Int J Colorectal Dis 2009, 24:209-218.

127. Steele NL, Plumb JA, Vidal L, Tjornelund J, Knoblauch P, Rasmussen A, et al: A phase 1 pharmacokinetic and pharmacodynamic study of the histone deacetylase inhibitor belinostat in patients with advanced solid tumors. Clin Cancer Res 2008, 14:804-810.

128. Gimsing P, Hansen M, Knudsen LM, Knoblauch P, Christensen IJ, Ooi CE, et al: A phase I clinical trial of the histone deacetylase inhibitor belinostat in patients with advanced hematological neoplasia. Eur $J$ Haematol 2008, 81:170-176.

129. Odenike O, Green M, Larson RA, Rich ES, Ott J: Phase I study of belinostat (PXD101) plus azacitidine (AZC) in patients with advanced myeloid neoplasms. J Clin Oncol 2008, 26:abstr 7057.

130. Mackay H, Hirte HW, Covens A, MacAlpine K, Wang L, Tsao MS: A phase II trial of the histone deacetylase inhibitor belinostat (PXD101) in patients with platinum resistant epithelial ovarian tumors and micropapillary/ borderline (LMP) ovarian tumors. A PMH phase II consortium trial. J Clin Oncol 2008, 26:abstr 5518.

131. Kuendgen A, Knipp S, Fox F, Strupp C, Hildebrandt B, Steidl C, et al: Results of a phase 2 study of valproic acid alone or in combination with alltrans retinoic acid in 75 patients with myelodysplastic syndrome and relapsed or refractory acute myeloid leukemia. Ann Hematol 2005, 84(Suppl 1):61-66.

132. Bug G, Ritter M, Wassmann B, Schoch C, Heinzel T, Schwarz K, et al: Clinical trial of valproic acid and all-trans retinoic acid in patients with poor-risk acute myeloid leukemia. Cancer 2005, 104:2717-2725.

133. Kuendgen A, Schmid M, Schlenk R, Knipp S, Hildebrandt B, Steidl C, et al: The histone deacetylase (HDAC) inhibitor valproic acid as monotherapy or in combination with all-trans retinoic acid in patients with acute myeloid leukemia. Cancer 2006, 106:112-119.

134. Garcia-Manero G, Kantarjian HM, Sanchez-Gonzalez B, Yang H, Rosner G, Verstovsek $S$, et al: Phase $1 / 2$ study of the combination of 5-aza-2'deoxycytidine with valproic acid in patients with leukemia. Blood 2006, 108:3271-3279.

135. Blum W, Klisovic RB, Hackanson B, Liu Z, Liu S, Devine H, et al: Phase I study of decitabine alone or in combination with valproic acid in acute myeloid leukemia. J Clin Oncol 2007, 25:3884-3891.

136. Soriano AO, Yang H, Faderl S, Estrov Z, Giles F, Ravandi F, et al: Safety and clinical activity of the combination of 5-azacytidine, valproic acid, and all-trans retinoic acid in acute myeloid leukemia and myelodysplastic syndrome. Blood 2007, 110:2302-2308.

137. Chavez-Blanco A, Segura-Pacheco B, Perez-Cardenas E, Taja-Chayeb L, Cetina $\mathrm{L}$, Candelaria $\mathrm{M}$, et al: Histone acetylation and histone deacetylase activity of magnesium valproate in tumor and peripheral blood of patients with cervical cancer. A phase I study. Mol Cancer 2005, 4:22.

138. Atmaca A, Al-Batran SE, Maurer A, Neumann A, Heinzel T, Hentsch B, et al: Valproic acid (VPA) in patients with refractory advanced cancer: a dose escalating phase I clinical trial. Br J Cancer 2007, 97:177-182.

139. Munster P, Marchion D, Bicaku E, Schmitt M, Lee JH, DeConti R, et al: Phase I trial of histone deacetylase inhibition by valproic acid followed by the topoisomerase II inhibitor epirubicin in advanced solid tumors: a clinical and translational study. J Clin Oncol 2007, 25:1979-1985.

140. Karpenko MJ, Liu Z, Aimiuwu J, Wang L, Wu X, Villalona-Calero MA, et al: Phase I study of 5-aza-2'-deoxycytidine in combination with valproic acid in patients with NSCLC. J Clin Oncol 2008, 26:abstr 3502.

141. Candelaria M, Gallardo-Rincon D, Arce C, Cetina L, guilar-Ponce JL, Arrieta O, et al: A phase II study of epigenetic therapy with hydralazine and magnesium valproate to overcome chemotherapy resistance in refractory solid tumors. Ann Oncol 2007, 18:1529-1538.

142. Katzel JA, Fanucchi MP, Li Z: Recent advances of novel targeted therapy in non-small cell lung cancer. J Hematol Oncol 2009, 2:2

143. Molckovsky A, Siu LL: First-in-class, first-in-human phase I results of targeted agents: Highlights of the 2008 American Society of Clinical Oncology meeting. J Hematol Oncol 2008, 1:20.

144. Yuan R, Kay A, Berg WJ, Lebwohl D: Targeting tumorigenesis: development and use of mTOR inhibitors in cancer therapy. J Hematol Oncol 2009, 2:45.

145. Cang S, Lu Q, Ma Y, Liu DL: Clinical advances in hypomethylating agents for epigenetic therapy of cancer. Current Cancer Drug Target 2010.

doi:10.1186/1756-8722-3-5

Cite this article as: Tan et al:: Novel histone deacetylase inhibitors in clinical trials as anti-cancer agents. Journal of Hematology \& Oncology $20103: 5$.

\section{Submit your next manuscript to BioMed Central and take full advantage of:}

- Convenient online submission

- Thorough peer review

- No space constraints or color figure charges

- Immediate publication on acceptance

- Inclusion in PubMed, CAS, Scopus and Google Scholar

- Research which is freely available for redistribution

Submit your manuscript at www.biomedcentral.com/submit 